\title{
Economic Analysis of Jatropha Bio-diesel Production in Sri Lanka
}

\author{
Sivashankar $\mathrm{P}^{1}$, Weerahewa $\mathrm{J}^{2}$, Pushpakumara $\mathrm{G}^{3}$ \& Galagedara $\mathrm{L}^{4}$ \\ ${ }^{1}$ Post Graduate Institute of Agriculture \\ ${ }^{2}$ Department of Agricultural Economics and Business Management, \\ ${ }^{3}$ Department of Crop Science, Faculty of Agriculture, University of Peradeniya, Sri Lanka. \\ ${ }^{4}$ Grenfell Campus, Memorial University of Newfoundland, Corner Brook, NL, Canada
}

\begin{abstract}
There has been an increasing trend in investments in renewable energy sources in the recent years. This study assesses the economic and financial feasibility of Jatropha production in Sri Lanka under the prevailing policy regime. The nominal protection coefficient and effective protection coefficients were employed to gauge the level of protection for bio-diesel production using Jatropha in Sri Lanka. The cost benefit analysis was performed to assess the feasibility of Jatropha bio-diesel production in Sri Lanka. The conventional measures like NPV, BCR, and IRR were used in financial and economic terms. Nominal Rate of Protection (NPR) was calculated by dividing the local Jatropha bio-diesel price by the border price of biodiesel. The NPR for Bio-diesel implies that nearly $47 \%$ of protection at local market level. Effective Protection Rate (EPR) for seed production is 90\%, for oil extraction and bio-diesel processing it is $128 \%$. Implication of this is that the producers will be protected and they receive returns $47 \%$ greater than what they would have received under free market conditions for Jatropha cultivation. Except for the benchmark situation, all other considered scenarios produce a favourable NPV, BCR and IRR for Jatropha bio-diesel production. Economic benefits due to CO2 reduction were also considered in the analysis.
\end{abstract}

KEYWORDS:Cost benefit Analysis, Jatropha Biodiesel, Protection Coefficient 


\section{INTRODUCTION}

Oil crises in the recent years have revealed the heavy dependence of industrialized countries on non renewable, finite fossil energy resources. This has led to immense investments on research and development of alternative renewable energy sources in the last two decades in many countries. Biofuel is such a renewable energy source which has been practiced and tested in many developing countries. This type of venture is environmentally friendly, since it reduces the green house gases. Emissions from burning fossil fuels are causing serious changes such as global warming and ozone depletion, which are expected to have significant long-term effects on the global climate. Benefits from biofuel production include reduction in carbon emissions, job creation, poverty alleviation, and improvement of socio-economic conditions of the rural people, especially the rural poor (Francis et al., 2005; Tomomatsu and Swallow, 2007; and Pushpakumara et al., 2008). Multidimensional long term benefits of biofuels have created a growing interest in biofuel production in the developing countries.

Commonest biofuel types are biodiesel and bioethanol. Bio-diesel is produced from oil crops like rapeseed (Brassica napus), sunflower (Helianthus annuus), Jatropha (Jatrophacurcas L.) and soybean (Glycine max) while bio ethanol is produced from starch crops like sugarcane, wheat and corn. Usage of food crops in bio-diesel production is a threat to food security. The current trend is bio-diesel extraction from non-edible, oil-bearing trees such as Jatropha, Pongamia, Castor and Neem (Lele, 2008).

Jatropha is a drought tolerant plant which can grow even in marginal conditions and is widely adapted to tropical climate (Francis et al., 2005 and Rajagopal, 2008). Its adaptability to marginal conditions is an advantageous feature, which other oil producing crops do not have (Pushpakumara et al., 2008), thus it has the ability to reclaim problematic lands and restore eroded areas (Francis et al., 2005). Among energy crops, Jatropha has been extensively practiced in developing countries of Asian, African, and Latin American continents. Countries in Asia and Africa have been involved in Jatropha cultivation mainly targeting the rural poor, with an expectation of alleviating poverty. Jatropha is not popular as an energy crop among Sri Lankans. The current Jatropha ventures are at initial stages and limited to investments made by NGOs, and private firms which receive foreign assistance. Its feasibility as a renewable energy source has not been adequately assessed in previous occasions.

Given this context, this study assesses feasibility of growing Jatropha for biodiesel production in Sri Lanka. Is it worth for Sri Lanka to produce Jatropha biodiesel? The objectives of this study are of two folds: (a) estimating the trade protection received by Jatropha farmers during Jatropha cultivation, Jatropha oil extraction and Biodiesel extraction levels and (b) assessing the financial and economic feasibility of Jatropha biodiesel production in Sri Lanka. Answers to these questions will support the debate, whether Jatropha biodiesel should be produced in Sri Lanka or not and whether these farmers receive a trade protection from importation of substitute products from neighboring countries. If the Jatropha production is economically feasible and farmers also receive a protection, Jatropha cultivation can be initiated to produce biodiesel. This would have positive implications in rural development as well as the Macroeconomic parameters.

\section{LITERATURE REVIEW}

Feasibility studies in Africa and in Indian states are more relevant to the research in question. A Kenyan based study has compared Jatropha with food crops. Study concludes that Jatropha is only feasible as a fence crop and should not 
be planted as a monocrop (Morra et al., 2009). If the fixed costs are minimized Jatropha production will be more cost effective than the food crops. Mogaka et al. (2010) studied the feasibility of using Jatropha as an alternative energy source for the rural households in the coastal areas of Kenya. The venture is profitable when the seed price is doubled and project worthiness parameters meet the satisfactory levels.

Potential of biofuel production from Jatropha cultivation in wastelands and subsequent socioeconomic development in degraded lands has been reported in India (Francis et al., 2005). Although large production may involve economies of scale a small decentralized system would be beneficial since it would include other benefits like creating employment, making fuel supply widely available and facilitation of redistribution of local by products.

Cost benefit analysis shows that rather than going up to Jatropha seed production, moving to biodiesel production and sale of by products would improve the venture's profitability. Improvements in market co-ordination and development of value chain and enhancing the extraction technology would further increase the parameters in concern i.e. NPV, IRR and BCR. The estimated socio economic benefits of long term Jatropha cultivation prove that the multifaceted benefits and opportunities could be utilized to improve rural livelihoods and rural area development.

Beerens (2007) show that large scale centralized system for Jatropha seed processing is viable than the decentralized pressing in Tanzania. For the same level of production, the centralized production gives an IRR of $61 \%$ compared to $30-40 \%$ of IRR in decentralized processing. Jatropha has a significant positive impact in the rural communities in Tanzania. Depending on the seed yield, the added value to the local community which consist about 9,000 inhabitants ranges from US\$12,750 to 54,500 . This is equal to 100 annual minimum wage rates. Pro-poor Jatropha production entirely for seeds was not economically viable in Kenya. It is more economical to include processing of biodiesel and substituting it for kerosene with higher IRR values than just selling the seeds. This proves that advanced biodiesel production for substituting kerosene is economically viable (Wekesa et al., 2009).

The other crucial aspect is the policies towards biofuel production. Inter alia, trade policies on biofuels have been gaining much attention in the recent past due to many countries shifting the momentum to produce and trade biofuels. Both developed and developing countries have implemented comprehensive policies to increase the share of biofuel to the national energy supply. Subsidies and other forms of tax rebates are among the policy decisions. Promising biofuel industries have been developed in west with the aegis of comprehensive policies from the respective governments (OECD, 2006). Even though there have been some initiation to promote renewable energy production, no special policies are available for Jatropha cultivation and biofuel trade in Sri Lanka.

The common method to study degree of protection and other export import policies for agricultural commodities are the nominal protection coefficient (NPC) and effective protection coefficients (EPC). Even though there are ample studies focused on food crops, no study has been done on the energy crops, especially on Jatropha. NPC of a commodity is the ratio of its domestic price to its border price. NPC does not account for input prices. The EPC is defined as the ratio of value added in domestic prices to value added in world prices, more completely, it measures the incentives to farmers.

The EPC indicates the combined effects of policies in the tradable commodities markets. This is a useful measure because input and output policies, such as commodity price supports and fertilizer subsidies, are usually a part of a comprehensive policy package for 
farmers (Conway and Bale, 1988). The EPC is crucial to producers since, it indicates the degree of protection provided to domestic production of import-competing goods. The EPC measure has been widely used both by governments to determine the level of protection to provide to domestic industries and by international organizations such as the World Bank (Elbehri and McDougall, 1998). Socioeconomic benefits of Jatropha have been also extensively studied by some authors (Francis et al., 2005).

\subsection{Sri Lankan Context}

Biomass (47\%), hydropower (8\%) and petroleum $(45 \%)$ are the main sources used for energy generation in Sri Lanka (UNESCAP, 2008). All petroleum products are imported. Increasing amount of biomass is also commercially grown and added. The average import price of crude oil (cif) of an average of US\$108.59 a barrel in 2011, a 36\% increase compared to the previous year (CBSL, 2011). Sri Lankan energy sector experienced a hit back when the international oil prices went up and the hydro power generation dropped due to unfavourable weather conditions. Total oil import bill increased by $58 \%$ to US $\$ 4.8$ billion in 2011.

Domestic retail prices for fuels were increased twice by Rs.24, Rs.11, and Rs.20 for petrol, diesel and kerosene respectively by the end of 2011. Sri Lanka Sustainable Energy Authority (SLESA) is looking at renewable energy sources to overcome this crisis. It expects to increase the share of renewable energy to generate power to $10 \%$ in 2015 and $20 \%$ by end of 2020. Investments have been made to generate solar energy and biomass energy (CBSL 2011).

This paves the path to look at alternative energy sources without sacrificing the food security of Sri Lanka. Thus, Jatropha biodiesel can be a viable option and research on Jatropha biodiesel could bring potential benefits to the society.

\section{PROTECTION ENVIRONMENT FOR JATROPHA SEED PRODUCTION AND BIODIESEL PRODUCTION}

The degree of protection was measured using Nominal Protection Rates (NPR) and Effective Protection Rates (EPR).

$N N P=(N P C-1) \times 100$
Where, $\quad N P C=\frac{P_{i}^{d}}{P_{i}^{W}} \quad$ and

$$
E P R=(E P C-1) \times 100
$$

Where,

$$
E P C_{i}=\frac{P_{i}^{d}-\sum_{j=1}^{k} a_{i j} P_{j}^{d}}{P_{i}^{W}-\sum_{j=1}^{k} a_{i j} P_{j}^{W}} \text { and }
$$

Where $P_{i}^{d}=$ Domestic price of output $i$, $a_{\mathrm{ij}}=$ unit of tradable input $\mathrm{j}$ per unit of output $I, P_{j}^{d}=$ Domestic price of tradable input $j$, $P_{i}^{w}=$ Border price of output $I$, $P_{j}^{w}=$ Border price of tradable input $j$.

The border price is defined as the price in the international market converted into local currency using an exchange rate. If the NPC > 1 , domestic producers are receiving a higher price after the policy intervention, thus protected. A NPC > 1, the consumer has to pay higher price for the commodity in concern. If the NPC $<1$ then the consumer gets a lower price and producer is discriminated. If the NPC $=1$, then the level of protection is neutral. The producers and consumers are facing the same domestic prices which are equal to the border prices they would have faced without the policy intervention (Tshakok, 1990). An EPC >1, indicates positive incentive effects of commodity policy (subsidy) whereas an EPC < 1 , shows negative incentives (a tax on farmers). EPC ignores the effects of transfers in the factor market and therefore do not reflect the full extent of incentives to farmers. 
The input output coefficients for Jatropha biodiesel production and world market prices were obtained from the Lele (2008). Tariff rates for the tradable inputs and world market prices for crude oil were obtained from the Central bank annual report 2011.The relevant tariff data for tradable goods were calculated using the tariff calculator of the Sri Lanka customs. They include Customs Duty, Port and Airport Development Levy (PAL 5\%), Value Added Tax (VAT 12\%), Excise Duty (20\%), Social and Responsibility Levy (SRL 1.5\%), and Nations Building Tax (NBT 1\%). The data and data sources are depicted below in Table 1 .

Table 1. Data and Data Sources

\begin{tabular}{|c|c|c|c|}
\hline Data & Value & Unit & Source \\
\hline Labour & 515 & Rs/man day & $\begin{array}{l}\text { Kahawat } \\
\text { te } \\
\text { Plantatio } \\
\mathrm{n}, 2011 .\end{array}$ \\
\hline Fertiliser & 26 & $\mathrm{Rs} / \mathrm{kg}$ & $\begin{array}{l}\text { GOSL, } \\
2011 .\end{array}$ \\
\hline Manure & 5,000 & Rs/lorry load & $\begin{array}{l}\text { DOA, } \\
2008 .\end{array}$ \\
\hline $\begin{array}{l}\text { Capital } \\
\text { cost }\end{array}$ & 11,850 & Rs & $\begin{array}{l}\text { Jatropha } \\
\text { World, } \\
2010 \text {. }\end{array}$ \\
\hline $\begin{array}{l}\text { Oil } \\
\text { extractor }\end{array}$ & 3.9 & Rs (mn) & $\begin{array}{l}\text { Jatropha } \\
\text { World, } \\
2010 \text {. }\end{array}$ \\
\hline $\begin{array}{l}\text { Other } \\
\text { inputs }\end{array}$ & 5,924 & Rs & $\begin{array}{l}\text { Jatropha } \\
\text { World, } \\
2010 \text {. }\end{array}$ \\
\hline $\begin{array}{l}\text { Biodiesel } \\
\text { processor }\end{array}$ & 6.2 & Rs (mn) & $\begin{array}{l}\text { Jatropha } \\
\text { World, } \\
2010 .\end{array}$ \\
\hline Operation & 233,549 & Rs & $\begin{array}{l}\text { Jatropha } \\
\text { World, } \\
2010 \text {. }\end{array}$ \\
\hline Methanol & 2.56 & $\mathrm{Rs} / \mathrm{kg}$ & $\begin{array}{l}\text { Jatropha } \\
\text { World, } \\
2010 \text {. }\end{array}$ \\
\hline $\begin{array}{l}\text { Sodium } \\
\text { Hydroxide }\end{array}$ & 7.68 & $\mathrm{Rs} / \mathrm{kg}$ & $\begin{array}{l}\text { Jatropha } \\
\text { World, } \\
2010 \text {. }\end{array}$ \\
\hline Biodiesel & 82.22 & $\overline{\mathrm{Rs} / \mathrm{l}}$ & $\begin{array}{l}\text { Jatropha } \\
\text { World, } \\
2010 \text {. }\end{array}$ \\
\hline $\begin{array}{l}\text { Fossil } \\
\text { Diesel }\end{array}$ & 84 & $\overline{\mathrm{Rs} / \mathrm{l}}$ & $\begin{array}{l}\text { CBSL, } \\
2012 .\end{array}$ \\
\hline
\end{tabular}

\begin{tabular}{|c|c|c|c|}
\hline Insurance & 20 & $\%$ & $\begin{array}{l}\text { Keyser, } \\
2006 .\end{array}$ \\
\hline $\begin{array}{l}\text { Unloading } \\
\text { Capital }\end{array}$ & 3,300 & Rs & $\begin{array}{l}\text { Hemas } \\
\text { Internatio } \\
\text { nal } \\
\text { Freight } \\
\text { Pvt Ltd } \\
2010 .\end{array}$ \\
\hline $\begin{array}{l}\text { Unloading } \\
\text { Chemical }\end{array}$ & 6 & $\%$ & $\begin{array}{l}\text { Keyser, } \\
(2006) .\end{array}$ \\
\hline $\begin{array}{l}\text { Transport } \\
\text { - Manure } \\
\end{array}$ & 50 & $\%$ & $\begin{array}{l}\text { Fernand } \\
\mathrm{o}, 2010 .\end{array}$ \\
\hline $\begin{array}{l}\text { Transport } \\
\text { and } \\
\text { Margin }\end{array}$ & 36 & $\%$ & $\begin{array}{l}\text { Keyser, } \\
(2006) .\end{array}$ \\
\hline \multicolumn{4}{|c|}{ Duties and taxes } \\
\hline Fertilizer & 72.36 & $\%$ & $\begin{array}{l}\text { CBSL } \\
\text { 2011, Sri } \\
\text { Lanka } \\
\text { Customs }\end{array}$ \\
\hline Capital & 68 & $\%$ & $\begin{array}{l}\text { CBSL } \\
\text { 2011, Sri } \\
\text { Lanka } \\
\text { Customs }\end{array}$ \\
\hline Chemical & 53.65 & $\%$ & $\begin{array}{l}\text { CBSL } \\
\text { 2011, Sri } \\
\text { Lanka } \\
\text { Customs }\end{array}$ \\
\hline Diesel & 11 & $\%$ & $\begin{array}{l}\text { CBSL } \\
\text { 2011, Sri } \\
\text { Lanka } \\
\text { Customs }\end{array}$ \\
\hline Biodiesel & 11 & $\%$ & $\begin{array}{l}\text { CBSL } \\
\text { 2011, Sri } \\
\text { Lanka } \\
\text { Customs }\end{array}$ \\
\hline
\end{tabular}

Table 2 shows the tradable inputs used in the process of biodiesel production and their respective factor shares. The last column depicts the output of each production level.

Machinery costs amounts for higher cost to produce a litre of biodiesel. Presently fertilizer has been subsidized for all crops at the rate of Rs. 1,200 for unmixed $50 \mathrm{~kg}$ fertilizer bag (i.e. Rs 24/kg). Rs. 1,300 for mixed fertilizer (i.e. Rs $26 / \mathrm{kg}$ ) and for paddy it is given for Rs. 350 per $50 \mathrm{~kg}$ bag ( $\mathrm{Rs} 7 / \mathrm{kg}$ ). Thus, for Jatropha it is given at the subsidy rate of $72.36 \%$. 


\subsection{Protection Coefficients}

Nominal and Effective protection coefficients reveal the level of protection an industry is receiving in the country with reference to the world market conditions and they provide a direction of the host countries policy orientation.

Table 3 depicts the NPC values for Biodiesel production at the border level and local market price level. NPR measures the trade protection on output. Local producers enjoy a protection of $86 \%, 85 \%$, and $47 \%$ respectively for Seed, Oil, and biodiesel production of Jatropha. This indicates on average the barriers to seed, oil, and biodiesel imports of Jatropha hold the domestic price at $86 \%, 85 \%$, and $47 \%$ above the import price and this is a positive protection to producers at the expense of consumers who have to pay a higher domestic price. Even inside the border the producers are protected at 50\% and $11 \%$ for seed and oil, and biodiesel, respectively.

Table 2: Tradable goods and factor shares according to level of Jatropha production

\begin{tabular}{|l|l|l|l|}
\hline Activity & $\begin{array}{l}\text { Tradable } \\
\text { Items }\end{array}$ & $\begin{array}{l}\text { Factor } \\
\text { Share }\end{array}$ & $\begin{array}{l}\text { Final } \\
\text { Product }\end{array}$ \\
\hline $\begin{array}{l}\text { Jatropha } \\
\text { Cultivation }\end{array}$ & Fertiliser & 0.018 & $\begin{array}{l}\text { Jatropha } \\
\text { Seeds }\end{array}$ \\
\hline $\begin{array}{l}\text { Jatropha } \\
\text { Oil } \\
\text { Extraction }\end{array}$ & Machinery & 0.64 & Oil \\
\hline \multirow{2}{*}{$\begin{array}{l}\text { Biodiesel } \\
\text { Production }\end{array}$} & KOchinery & 1.024 & \\
\cline { 2 - 4 } & KoH & 0.008 & Biodiesel \\
\cline { 2 - 3 } & Methanol & 0.003 & \\
\hline
\end{tabular}

Source: Author's calculations

Table 3: NPC and NPR Values inside the border and at local market prices

\begin{tabular}{|l|l|l|}
\hline Stage & Inside the Border & $\begin{array}{l}\text { Local } \\
\text { Market }\end{array}$ \\
\hline $\begin{array}{l}\text { Jatropha Seed } \\
\text { Production }\end{array}$ & $1.50(50 \%)$ & $1.86(86 \%)$ \\
\hline
\end{tabular}

\begin{tabular}{|l|l|l|}
\hline $\begin{array}{l}\text { Jatropha Oil } \\
\text { Extraction }\end{array}$ & $1.49(49 \%)$ & $1.85(85 \%)$ \\
\hline $\begin{array}{l}\text { Biodiesel } \\
\text { Production }\end{array}$ & $1.11(11 \%)$ & $1.47(47 \%)$ \\
\hline
\end{tabular}

Source: Author's calculations, *NPR values are within parenthesis

Table 4: EPCs for different production levels

\begin{tabular}{|l|l|l|}
\hline Stage & $\begin{array}{l}\text { Inside the } \\
\text { Border }\end{array}$ & $\begin{array}{l}\text { Local } \\
\text { Market }\end{array}$ \\
\hline Jatropha Seed & $1.49(49 \%)$ & $1.90(90 \%)$ \\
\hline Jatropha Oil & $1.68(68 \%)$ & $2.28(128 \%)$ \\
\hline Biodiesel & $1.68(68 \%)$ & $2.28(128 \%)$ \\
\hline
\end{tabular}

Source: Author's calculations, *EPR values are within parenthesis

EPC measures the degree of protection on both output and input. EPC has to be calculated to grab the effects of trade policies on tradable inputs. Thus, trade policies like taxes and subsidies to inputs will be also accounted in EPC. Table 4 presents the EPC values for different levels of biodiesel productions at the border and at local market. Within the border of Sri Lanka, seed, oil, and biodiesel, all three are protected around $50 \%, 68 \%$, and $68 \%$ above the CIF price, respectively. For seed protection at local market, input fertilizer is subsidized at $73 \%$ below the world market price. It derives an EPR of $90 \%$ for seed production which implies an incentive for producers. Further, Jatropha oil and biodiesel is protected $128 \%$ above the CIF price, giving a clear protection for local Jatropha producers. Since all the EPC values are above unity this industry is effectively protected against imports. Even though, tradable inputs are taxed, the output's tariff rate is higher than the tariff on tradable inputs. Thus, effective protection for Jatropha is high.

\section{FINANCIAL AND ECONOMIC BENEFIT COST ANALYSIS OF JATROPHA SEED PRODUCTION AND BIODIESEL PRODUCTION}

Project worthiness was assessed using few key indicators, viz. net present value, internal rate of return and benefit cost ratio of the project. 
These three are the most commonly used indicators to measure the project worthiness and has been used in many feasibility studies of Jatropha biodiesel production. Net present value is computed by finding the difference between the present worth of benefit stream less the present worth of cost stream.

$$
N P V=\sum_{i=1}^{n} \frac{R_{i}-C_{i}}{(1+r)^{n}}
$$

Where, $\mathrm{Ri}=$ Gross Return of the ith year, $\mathrm{Ci}=$ Cost incurred in ith year, $\mathrm{n}=$ Planning period

Benefit to Cost Ratio (BCR) is the ratio of present worth of benefit stream to present worth of cost stream. The investment is said to be profitable when the BCR is one or greater than 1. This method is widely used in economic analysis and not in private investment analysis.

$$
B / C \text { Ratio }=\frac{\sum P V B}{\sum P V C}
$$

Where, $P V B=$ Present Value Benefit, and $P V C=$ Present Value Cost

Internal Rate of Return (IRR) is the discount rate which just makes the NPV of the cash flow equal zero. It represents the average earning power of the money used in the project over the project life. It is also called yield of the investment. Jatropha cultivation and biodiesel extraction project was considered to be continued for 20 years. Capital equipments were depreciated at the end of each year by $5 \%$ and considered no salvage value at the end of 20th year. The cost components included all the activities from land preparation to seed cultivation, oil extraction, and biodiesel tranesterification. The cost of producing a planting material (i.e. a cutting or seedling) was assumed as Rs. 35. During the first year, 2500 plants were assumed to be planted per hectare and 500 plants were considered to be necessary for replanting. In total 100 plants were allocated for one man-day and 25 and 5 man-days/ha were estimated during the first and second year, respectively. In the first instance, a cost-benefit analysis was conducted under assumed technical production parameters. The considered technical parameters are, a) 1.33 $\mathrm{kg} / \mathrm{plant} /$ year, b) $30 \%$ biodiesel extraction, c) 2 $\mathrm{m} \times 2 \mathrm{~m}$ spacing, d) 20 years of crop lifespan, e) $10.5 \%$ discount rate, f) Rs. 120/1 of biodiesel price, g) Full wage rate i.e. Rs. 515. Income components were mainly biodiesel and byproduct sales.

Project worthiness was assessed by estimating NPV, IRR and BCR. At next, key variables were identified from the earlier CBA and they were altered at feasible levels to conduct a sensitivity analysis. This analysis was done in two scenarios. At first scenario it was with fully hired labour and the second was with half of the labour requirement replaced by family labour. Key variables chosen for the sensitivity analysis are, I) seed yield (1.33 and $2.00 \mathrm{~kg} / \mathrm{plant} /$ year), II) by products (with and without scenario), and III) hired labour versus Family labour. Finally worthiness of the each project was assessed and compared with the baseline data.

Table 5 depicts the Project worth measures both in terms of financial and economic analysis terms. Since economic benefits are high due to CDM opportunities in this project the economic analysis is more feasible than financial analysis. With full wage level all the scenarios are feasible except the baseline scenario. At benchmark level, a negative NPV is obtained with a unit BCR and $10 \%$ IRR. This level is not feasible in financial terms. In economics term, the project is worth as NPV reaches LKR $18 \mathrm{mn}$ with $21 \%$ higher returns (BCR 1.21) and $16 \%$ of IRR. The considered discount rate is $10.5 \%$. For a 147 ha Jatropha plantation around 200 man days of employment is generated in the first year and 50 man days are generated from the second year onwards. Thus totally 1150 man days of employment is generated by this project. Moreover, income generation from $\mathrm{CO} 2$ reduction per year for a hectare is around LKR 4024. For the total project period the 
income from $\mathrm{CO} 2$ reduction amounts to $\mathrm{LKR}$ $11,829,825$. The all the other scenarios show that the project is worthwhile with sufficient NPV, BCR and IRR. Since there are less environmental damage and more environmental benefits, those will be accounted for the benefits in the economic analysis. Thus, economic analysis exceeds the financial analysis.

Cost benefit analysis has been used in other studies related to Jatropha Biodiesel production. However their results do not show a favourable scenario. Studies extending to economic cost benefit analysis are scarce. Van Eijck et al. (2012) concludesJatropha Biodiesel production incurs higher costs than conventional diesel. Further resource extansive cultivation yields less returns due to poor resource inputs. Another study by Van Eijck et al. (2013) finds that until better varieties and techniques are developed Jatropha biodiesel production will only be limited to poor and disadvantaged areas. Poor and unreliable yiled is a major problem in Jatropha. Cynthia and Teong (2011), Mogaka et al. (2012), Nevase et al. (2012) also pinpoints the critical issues in this Jatropha venture. They highlight the issue that availability of data and assumptions play a major role in cost benefit analysis. The reliability of the analysis depends on the accurate estimations and the expected cash flows. Starting from accurate yield estimations to expected environmental benefits all have to be accurately identified.

A similar analysis by Mogaka et al. (2012) finds Jatropha venture is not feasible in Kenya given the current institutional setup. In Most of the studies, the analysis is too early or the Jatropha plantations have just being established. Some have failed to prodcue expected yield returns. Given the reality, in this analysis, it will be important to obtain higher yeilds and higher oil content in the Jatropha seed.

Since the venture is domestically protected against imports farmers will not have a competition. But the competing resource like labor would be crucial as this will be drawn from the existing labor markets. Since other countries have also heavily protected the agriculture sector it would be difficult to export the product. The current trend has been a fluctuation of conventional diesel prices and it is being kept high due to the higher tax rate being implemented. So for Jatropha biodiesel to be marketable it has to be below the market price of diesel. But the current trends in diesel are that prices are declining after 2012. It will be difficult to produce biodiesel when diesel prices are kept low.

Table 5: NPV, BCR, and IRR values for Jatropha Biodiesel Production

\begin{tabular}{|c|c|c|c|c|c|}
\hline & & \multicolumn{2}{|c|}{$\begin{array}{l}\text { Financial } \\
\text { Analysis }\end{array}$} & \multicolumn{2}{|c|}{$\begin{array}{l}\text { Economic } \\
\text { Analysis }\end{array}$} \\
\hline & & 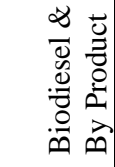 & 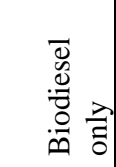 & 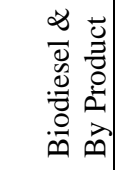 & 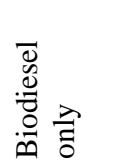 \\
\hline \multirow{3}{*}{ 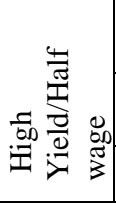 } & $\begin{array}{l}\mathrm{NP} \\
\mathrm{V} \\
\end{array}$ & $\begin{array}{l}49.33 \\
\mathrm{mn}\end{array}$ & $\begin{array}{l}26.66 \\
\mathrm{mn}\end{array}$ & $\begin{array}{l}59.3 \\
\mathrm{mn}\end{array}$ & $\begin{array}{l}30.84 \\
\mathrm{mn}\end{array}$ \\
\hline & $\begin{array}{l}\mathrm{BC} \\
\mathrm{R} \\
\end{array}$ & 1.48 & 1.26 & 1.60 & 1.31 \\
\hline & IRR & 0.19 & 0.16 & 0.20 & 0.17 \\
\hline \multirow{3}{*}{ 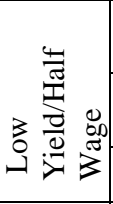 } & $\begin{array}{l}\mathrm{NP} \\
\mathrm{V}\end{array}$ & $\begin{array}{l}36.9 \\
\mathrm{mn}\end{array}$ & $18 \mathrm{mn}$ & $\begin{array}{l}41.77 \\
\mathrm{mn}\end{array}$ & $\begin{array}{l}18.98 \\
\mathrm{mn}\end{array}$ \\
\hline & $\begin{array}{l}\mathrm{BC} \\
\mathrm{R} \\
\end{array}$ & 1.41 & 1.20 & 1.47 & 1.21 \\
\hline & IRR & 0.18 & 0.15 & 0.19 & 0.15 \\
\hline \multirow{3}{*}{ 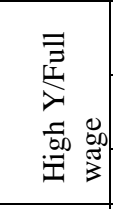 } & $\begin{array}{l}\mathrm{NP} \\
\mathrm{V} \\
\end{array}$ & $\begin{array}{l}66.94 \\
\mathrm{mn}\end{array}$ & $\begin{array}{l}44.5 \\
\mathrm{mn}\end{array}$ & $\begin{array}{l}98.25 \\
\mathrm{mn}\end{array}$ & $71.7 \mathrm{mn}$ \\
\hline & $\begin{array}{l}\mathrm{BC} \\
\mathrm{R} \\
\end{array}$ & 1.79 & 1.53 & 2.72 & 2.25 \\
\hline & IRR & 0.20 & 0.18 & 0.25 & 0.24 \\
\hline \multirow{3}{*}{ 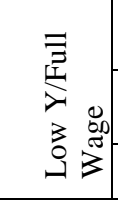 } & $\begin{array}{l}\mathrm{NP} \\
\mathrm{V} \\
\end{array}$ & $\begin{array}{l}24.4 \\
\mathrm{mn}\end{array}$ & $\begin{array}{l}-0.4 \\
m n *\end{array}$ & $42 \mathrm{mn}$ & $18.5 \mathrm{mn}$ \\
\hline & $\begin{array}{l}\mathrm{BC} \\
\mathrm{R} \\
\end{array}$ & 1.23 & 1.00 & 1.47 & 1.21 \\
\hline & IRR & 0.16 & 0.10 & 0.20 & 0.16 \\
\hline
\end{tabular}

Source: Author's calculations, *benchmark scenario, NPV in Rs.

\section{CONCLUSION}

The findings of the present study in terms of nominal and effective protection to the 
Jatrophabiodiesel industry conclusively suggests that the manufacturing of biodiesel in Sri Lanka, under the current trade regime, will be import substitution oriented, and the current additional tariffs involved makes Sri Lanka more protected against imports even though trade liberalization has occurred literally. Further if the production cost is high then the government will have to subsidize it. There are practical limitations to produce Jatropha biodiesel in par with the conventional diesel price at local market. Thus, it has to be used as an additional income earning crop to rural households. If the NPC to be used as a policy structure, and there by other changes within the market, the domestic and border prices used must represent the price values of the decision makers actually would have encountered in the real situation before and after the intervention. Production incentives introduced by the trading governments, exchange rates, and input pricing policies are of interest to trade economist and EPC is the commonly accepted gauge to measure level of protection. Despite the shortcomings EPC's are widely used to get the gist of the trade policies in concern. Production incentives introduced by the trading governments, exchange rates, and input pricing policies are of interest to trade economist and EPC is the commonly accepted gauge to measure level of protection. A general equilibrium approach to measure the EPC's would be more comprehensive and indicative about a policy rather than using a partial equilibrium approach. Despite given the shortcomings EPC's are widely used to get the gist of the trade policies in concern.

The results of cost benefit analysis reveal that the Jatropha production for biodiesel is financially and economically feasible in Sri Lanka given the favourable yields of the plant. Further, a support from the government would help to establish a Jatropha supply chain. However the literature suggests that cross country experiences in Jatropha cultivation cannot be shared and vary depending on the host country climate, management and varieties.
From the government's perspective, it has to propose a comprehensive policy package that would cater to both the producers and consumers. It is crucial for the government to actively get involved in harnessing the opportunities created by the introduction of renewable bio-energy in order to remove the adverse effects created to the stakeholders. Improvement of technology, developing international and national technical and commercial information flow, development of markets and creating land availabilities are some areas government needs to pay immediate attention.

\section{ACKNOWLEDGEMENT}

Financial assistance given by National Science Foundation of Sri Lanka (RG/2009/Biofuel 002) is acknowledged.

\section{REFERENCES}

BEERENS P. Screw-pressing of Jatropha seeds for fuelling purposes in less developed countries. Unpublished thesis. Masters in Sustainable Energy Technology, Eindhoven Energy Technology, Eindhoven, The Netherlands. 2007.

CENTRAL BANK OF SRI LANKA. Annual Report 2011, Colombo, Sri Lanka. 2012.

CONWAY PJ, BALE M. Approximating the effective protection coefficient without reference to technological data. The World Bank Economic Review.1998; 2(3): 349-63.

CYNTHIA OB, TEONG LK. Feasibility of Jatropha oil for biodiesel: Economic Analysis. World Renewable Energy Congress, Linkoping, Sweden. 8-13th May, 2011.

ELBEHRI A, MCDOUGALL RA. Data base summary: effective rates of protection. In McDougall RA, Elbehri A, Truong TP, editors. Global trade assistance and protection: The GTAP 4 database. Center for Global Trade 
Analysis,

Purdue

University.1998.http://www.gtap.agecon.purdue .edu/databases/v4/v4_doco.asp. Accessed 11 June 2011.

EIJCK J VAN, SMEETS E, FAAIJ A. The economic performance of Jatropha, Cassava and Eucalyptus production systems for energy in an East African smallholder setting. GCB Bioenergy 2012;4:828-845.

EIJCK J VAN, COLTHOFF JR, ROMIJN H, HEIJNEN S, RUIJTER F, JONGSCHAAP R. Jatropha sustainability assessment, data from Tanzania, Mali \& Mozambique. Commissioned by NL Agency. 2013.

FERNANDO NI, NILMINI S. Does simple marketing techniques applicable to farm gate level of up-country vegetables? A case for Welimada area, Badulla district. International Conference on Business \& Information. Faculty of commerce \& management studies. University of Kelaniya, Sri Lanka. 2010.

FRANCIS G. EDINGER R. BECKER K. A concept for simultaneous wasteland reclamation, fuel production, and socioeconomic development in degraded areas in India: Need, potential and perspectives of Jatropha plantations. Natural Resource Forum. 2005; 29: 12-24.

RAJAGOPAL R. Best Practices for Long-term Jatropha Development. Position paper published by KnowGenix. 2008.

LELE S. Economics of Jatropha production 2008. http://www.svlele.com. Accessed 11 Jan 2011.

MOGAKA VM, MIYUKI I, MBATIA OLE, NZUMA J. Reality or romantism? potential of Jatropha to solve energy crisis and improve livelihoods. 48th Agricultural Economists Association of South Africa Conference, Cape Town, South Africa, Sep 19-23, 2010. http://ageconsearch.umn.edu/bitstream/97056/2/
86.\%20Jatropha\%20in\%20Kenya.pdf. Accessed 27 Jan 2011.

MOGAKA VM. MBATIA OLE. JONATHAN N. Feasibility of Biofuel Production in Kenya: The Case of Jatropha. International Association of Agricultural Economists (IAAE) Triennial Conference, Foz do Iguaçu, Brazil, 18-24 August, 2012.

MORRA V, IIYAMA M, NZUMA J, MUNSTER C, MBATIA OLE, HUNSBERGER C. Food or Jatrophacurcas for biodiesel production? A cost benefit analysis in Kwale district. 2009. http://www.devstud.org.uk/aqadmin/media/uplo ads/4ab7932aef52a_12-mogaka-dsa09.pdf.

Accessed on 27 Jan 2011.

NEVASE SS, GADGE SR, DUBEY AK, KADU BK. Economics of biodiesel production from Jatropha oil. Journal of Agricultural Technology. 2012; 8(2): 657-662.

OECD. Agricultural market impacts of future growth in the production of biofuels. working party on agricultural policies and markets, committee for agriculture, directorate for food, agriculture and fisheries, Organisation for Economic Co-operation and Development, AGR/CA/APM(2005)24/FINAL. 2006.

PUSHPAKUMARA DKNG, GUNASENA, HPM, SINGH VP. Jatropha (Jatrophacurcas L.): A potential biodiesel crop for Sri Lanka. The World Agroforestry Centre, South Asia Office, New Delhi, India and National Multipurpose Tree Species Research Network of Sri Lanka. 2008.

TOMOMATSU Y, SWALLOW B. Jatrophacurcas biodiesel production in Kenya: economics and potential value chain development for smallholder farmers. Working paper No. 54, Nairobi, World Agroforestry Centre, 2007. 
TSHAKOK I. Agricultural Price Policy: A Practitioner Guide to Partial Equilibrium Anaysis. 1st ed. Ithaca NY: Cornell University Press. 1990.

UNESCAP. Sri Lanka - Country Paper. 2008.http://www.unescap.org/esd/energy/dialog ue/community/documents/Country\%20paper\%2 0Sri\%20Lanka.pdf Accessed 12 May 2010.

WEKESA LRN. WAMAHIU P. ESILABA A. MUTURI G. Economic analysis of Jatrophacurcas L. potential for bio diesel production in Kenya. 2009. http://www.kari.org/biennialconference/confere nce $12 /$ docs/ECONOMIC\%20ANALYSIS\%20 OF\%20JATROPHA\%20CARCUS\%20L.\%20P OTENTIAL\%20FOR\%20BIODIESEL\%20PR ODUCTION\%20IN\%20KENYA.pdf. Accessed 27 Jan 2011 